\title{
Comparing Cross-Cultural Dimensions of the Experiences of International Tourists in Vietnam
}

\author{
Thuy-Huong Truong and Brian King \\ Victoria University, Australia
}

\begin{abstract}
Vietnam's location in South East Asia places it well to benefit from tourism growth trends regionally and globally. It appeals to international tourists because of its long history, its culture and its unique customs and habits. Vietnam is experiencing rapid international tourism growth of visitors from different cultural backgrounds which places pressure on tourism service providers. If development is to be well managed, tourism professionals will need to broaden their understanding of both Western and Asian visitors, and managers need to encourage an atmosphere of familiarity and comfort amongst tourist groups, thus enhancing visitor satisfaction. However, appealing to diverse tourists markets is difficult because the needs of visitors are culturally determined and complex. Despite the importance of tourism for Vietnam, no research has attempted to measure tourist satisfaction in a cross-cultural context. In the present paper, a conceptual framework is proposed to explain the determinants of satisfaction amongst international tourists from different cultures when holidaying in Vietnam. In developing the proposed model, a review is undertaken of the concepts of culture, rules of behaviour, tourist perception and satisfaction. A range of factors are take into account including internal factors (such as cultural values, rules of behaviour, sociodemographics, behavioural and other travel characteristics) and external factors including tourist perceptions of their hosts and of products and services.
\end{abstract}

\section{Introduction}

Vietnam is endowed with abundant historical and cultural heritage and offers a variety of beautiful and unspoiled natural attractions. Such attributes have potential appeal for a wide cross-section of travellers. Its tourist attributes lend themselves to the development of a diverse range of products from coastal and beach tourism settings to adventure, ecotourism, cultural heritage and urban tourism. Vietnam's economic reforms have given further impetus to the growth of international tourism prompting the upgrading of tourism facilities and gradual relaxation of entry requirements.

Since 1990, Vietnam's tourism industry and tourism receipts have been transformed into one of the country's leading sectors. Tourism is now one of Vietnam's leading exports. According to official

Copyright (C) 2006 Victoria University. This document has been published as part of the Journal of Business Systems, Governance and Ethics in both online and print formats. Educational and non-profit institutions are granted a nonexclusive licence to utilise this document in whole or in part for personal or classroom use without fee, provided that correct attribution and citation are made and this copyright statement is reproduced. Any other usage is prohibited without the express permission of the
VNAT (Vietnam National Administration for Tourism) (2005) forecasts, inbound tourism will be maintained and will reach 2.3 million growing to around 6 million in 2010. Vietnam appeals to holidaymakers who are seeking novel and exciting destinations. It is also popular with independent travellers following the East Asia back-packers route. As is evident from the international tourist arrival trends over the period 2000 to 2005 , highlighted in 
Table 1, Vietnam is already accustomed to handling inbound travellers from different cultural backgrounds. China, France and the USA currently account for nearly $50 \%$ of total overseas arrivals in Vietnam. They have been selected as the subjects of the present research. Though each exhibits distinct cultural characteristics, they all have strong historical and cultural links with Vietnam.

The combination of affordability and proactive promotion by the Vietnamese government has stimulated strong inbound tourism growth. As various air transport links have been fully re-established, Vietnam will be placed to take advantage of the Chinese, French and American leisure, business and VFR markets. The depreciation of the Vietnamese Dong relative to the USA and China currencies has enhanced the affordability of Vietnam as a destination.

Table 1: International Tourist Arrivals to Vietnam by Major Countries (2000-2005)

\begin{tabular}{|l|r|r|r|r|r|}
\hline Nationality & $\mathbf{2 0 0 1}$ & $\mathbf{2 0 0 2}$ & $\mathbf{2 0 0 3}$ & $\mathbf{2 0 0 4}$ & $\mathbf{2 0 0 5}$ \\
\hline China & 672,846 & 724,385 & 639,423 & 778,431 & 684,054 \\
\hline Japan & 204,860 & 279,769 & 209,730 & 267,210 & 298,979 \\
\hline Taiwan & 200,061 & 211,072 & 207,866 & 256,906 & 260,987 \\
\hline USA & 230,470 & 259,967 & 218,928 & 272,473 & 299,442 \\
\hline France & 99,700 & 111,546 & 86,791 & 104,025 & 114,779 \\
\hline Australia & 84,085 & 96,624 & 93,292 & 128,661 & 132,398 \\
\hline Britain & 64,673 & 69,682 & 63,348 & 71,016 & 73,828 \\
\hline Thailand & 31,789 & 40,999 & 40,123 & 53,682 & 77,599 \\
\hline Total & $1,588,484$ & $1,794,044$ & $1,559,501$ & $1,932,404$ & $1,942,066$ \\
\hline Grand Total & $2,330,050$ & $2,627,988$ & $2,073,433$ & $2,927,876$ & $3,140,426$ \\
\hline
\end{tabular}

Source VNAT (2005)

Despite the various comparative studies within the customer satisfaction literature, and despite the importance of tourism for Vietnam, no specific tourist satisfaction research has been focussed on Vietnam apart from a single investigation by Truong (2002). Since the production and distribution of international tourism services form an integral component of the cross-cultural experience, they impact upon tourism service providers. Given the marked differences between the cultures of Asian travellers and their Western counterparts, it will be critical for Vietnam's tourism service providers to understand the perceptions and satisfaction of visitors from different cultures with various tourist products and services, including their Vietnamese hosts. The current study proposes a model to investigate the cultural differences, the rules of behaviour and relative perception and satisfaction levels of American, French and Chinese tourists when visiting Vietnam. It will also take into account the cultural differences between tourists and Vietnamese tourist providers.

\section{Concept of Cultures and Values}

Culture has been defined and conceptualized drawing upon a range of social science disciplines including anthropology, sociology, psychology, intercultural communication, marketing and management. The various prevailing definitions range from viewing culture as "everything" to a narrower view. Most studies refer to culture in its "broader" sense in psychological terms such as values, norms, rules, behaviour, perceptions, attitudes, beliefs, symbols, knowledge, ideas, meanings, thoughts (Bennett \& Kassarjian, 1972; Argyles 1978; Peterson, 1979; Leighton, 1981; Camilleri, 1985; Ember \& Ember, 1985; Mill \& Morrison, 1985; Moutinho, 1987; Robinson \& Nemetz. 1988; Kim \& Gudykunst, 1988). Though there are various definitions of culture in the literature, there is general agreement that it is a "theory" (Kluckhohn, 1944), an "abstract" or a "name" for a very large category 
of phenomena (Moore \& Lewis, 1952). The present study has drawn upon this range of definitions to analyse the national cultures of Vietnamese hosts and international tourists to Vietnam. Special emphasis is given to Kroeber \& Kluckhohn's (1952) definition as it provides the basis for the study objectives with its emphasis on culture as values, rules of social behaviour, perceptions, and differences and similarities between people. This particular definition was chosen because it appears to accommodate the view that the cross-cultural satisfaction of tourists and service providers is influenced by the differences and similarities evident amongst tourist and host cultural values and perceptions.

Values may be defined as culturally determined standards of socially desirable behaviour, which influence rules of social behaviour and perceptions. They are prevalent amongst people within the same culture and distinguish them from those emanating from others. As a means of differentiating between cultures and explaining cultural differences, they have clear advantages. Kluckhohn (1952, p.395) has defined a value as "a conception, explicit or implicit, distinctive of an individual or characteristic of a group, of the desirable which influences the selection from available modes, means and ends of actions". Consistent with this definition, Rokeach $(1973$, p.5) characterised a value as "an enduring belief that a specific mode of conduct or end-state of existence is personally preferable to an opposite mode of conduct or end-state of existence". According to Pizam et al. (1997), cultural values involve shared values, beliefs and norms that collectively distinguish a particular group of people from others as well as different perceptions of what is considered appropriate behaviour. These widely shared values are programmed into individuals in subtle ways from quite an early age (Otaki et al., 1986), are resistant to change (Hofstede 1991) and remain evident when at home or while travelling abroad (Pizam and Reichel 1996).

National culture has been defined in numerous ways (Erez and Earley 1993). Based predominantly on the work of Kluckhohn and Strodbeck (1961) and Hall $(1976,1983,1996)$, there is substantial empirical evidence of differences between the cultural value patterns of Eastern and Western societies. The most widely referenced dimensions of culture are undoubtedly the five presented by Hofstede (1980) and Hofstede and Bond (1988) using an instrument known as the Values Survey Module (VSM). These may be summarised as follows: (a) power distance (a tolerance for class differentials in society); (b) individualism (the degree to which welfare of the individual is valued more than the group); (c) masculinity (achievement orientation, competition, and materialism); (d) uncertainty avoidance (intolerance of risk); and later (e) the Confucian dynamic, or long-term orientation (stability, thrift, respect for tradition and the future). According to Hofstede (1991), Asian societies may be characterized as scoring high in terms of long-term orientation, collectivism and power distance, but exhibiting mixed results in terms of masculinity and uncertainty. Western societies by contrast tend to score lower on long-term orientation, collectivism, power distance and uncertainty avoidance, but are mixed in terms of masculinity. For the purposes of the study, it is hypothesised that the cultures of Chinese, French and American tourists are different.

\section{Cross-Cultural Measurement}

The role attributed to national or cultural characteristics as determinants of tourist behaviour has been given limited attention, though there is evidence of growing interest being shown amongst tourism researchers. Pizam (1999) has proposed the use of direct or indirect methods when carrying out crosscultural research in consumer behaviour. Researchers have used empirical methods to discover any differences between the behaviour of tourists of different ethnicities and/or nationalities by using direct methods. Using the diary method, Ibrahim (1991) noted differences between the leisure behaviour of various nationalities. Tourist behaviour studies employing indirect methods were conducted via surveys of resident perceptions of tourists or tourism practitioner perceptions of tourists. Pizam and TelismanKosuta (1989) found that residents in destination areas perceived tourists as exhibiting a variety of behavioural characteristics and lifestyles that distinguish them from locals. From these examples, it is clear that nationality exerts considerable influence over consumer or tourist behaviour. In terms of attitudes and behaviour, such differences focus on the importance of exploring the features of each 
customer group, segmenting tourism markets and releasing new marketing strategies, which are appropriate for each market with a view to achieving effective destination management. Decision makers within tourist destinations which attract visitation from different cultures and countries will need to have an advanced understanding of the behaviour of tourists from different cultural backgrounds.

\section{Perceptions}

Perception is an important element of culture. Perceptions are based on physiology (the five senses) and also have characteristics related to demography, behaviour, society, culture, economics and psychology (Usunier, 2000). Culture is particularly important as a determinant of perceptions and has a great influence on how experiences are perceived and also on interpreted meanings (Samovar \& Porter, 1991). McCracken (1986) has referred to "culture" as a lens through which people view the world. Somewhat similarly perceptions are defined as the process through which people see the world around them (Schiffman and Kanuk, 1987) or as "the impressions people form of one another and how interpretations are made concerning the behaviour of others" (Hargie 1986, p. 47). Cultural influences may be viewed as influencing how people perceive and assimilate phenomena. Wei et al. (1989) observed that cultural differences lead to different perceptions of what constitutes appropriate behaviour (p. 329). Given that worldviews are very diverse, it is perhaps unsurprising that perceptions also differ (Krech \& Crutchfield, 1948; Robertson, 1970). Perceptions rely on cultural values, expectations, experiences and interests and are culturally determined.

Three types of perceptions play an important role in social interactions: (1) perceptions of other people; (2) perceptions of oneself and (3) perceptions of the perceptions (meta-perceptions). Perceptions play an important part in social interactions (Cook 1979). Rules of social interaction influence the development of social perceptions and differ across cultures. Generally speaking, cultural similarities within perceptions will encourage social interaction whereas dissimilarities will discourage it. The quality of interactions and associated holiday satisfaction involves the extent of similarity between the cultural values systems of tourists and hosts (Pearce and Moscardo, 1984). Culture determines perceptions of service quality and thus satisfaction with social interaction in the delivery of a service. Perceptions of others, namely tourist and host perceptions of one another, will be analysed in the present paper. Host perceptions of tourists are important because they are key points for the identification of tourist perceptions of hosts. Tourist perceptions of hosts on the other hand will influence the selection of a holiday destination and will determine tourist satisfaction and the likelihood of repeat visitation.

Researchers have become increasingly involved in examining the various dimensions of the tourist perspective. The findings of previous cross-cultural research have confirmed that tourist perceptions of a destination or of service providers may vary on the basis of country of origin (Richardson \& Crompton, 1988; Calantone, Di Benedetto, Halam \& Bojanic, 1989; Luk, De Leon, Leong \& Li, 1993; Huang \& Wu, 1996; Armstrong, Mok, Go \& Chan, 1997). Pizam \& Sussmann (1995) investigated tour guide perceptions of similarities and differences between tourists from four countries. The same survey was subsequently repeated among Israeli tour guides (Pizam \& Reichel, 1996). In both studies, tour guides perceived that different behavioural characteristics were evident amongst tourists from different nationalities.

A number of studies have examined host perceptions of tourists. Undertaken in Mexico, Brewer's (1984) study concluded that local residents have "general" stereotypes of all Americans, which lead to "specific" stereotypes which are then applied to American tourists. Pi-Sunyer (1978) found that Catalans stereotype English tourists as stiff, socially conscious, honest, and dependable. Boissevain \& Inglott (1979) observed that the Maltese characterized Swedish tourists as misers, and the French and Italians as excessively demanding. Since these factors have the prospects of influencing tourist perceptions negatively, it is important to determine host perceptions of tourists and whether or not hosts are accepting of tourists. 
The literature has indicated that there is a significant relationship between culture and perceptions. Perceptions of the world are influenced by the culture into which one has been socialized and it is important to have a proper understanding of cultural value orientations that affect perceptions. Most tourism and hospitality industry employees appear to acknowledge the existence of tourist cultural differences either implicitly or explicitly in terms of interests, needs, expectations, destination or hotel selection and activities preferred. Destination image and perceptions appear to influence vacation choice decisions and national cultural characteristics appear to affect tourist perceptions. According to Gee (1986), tourist perceptions of hosts are the most important of the various tourist perceptions. Any examination of the tourist perceptions of the performance of service providers will need to highlight any negative perceptions and indicate how they may be changed or modified leading to better responses to the needs of tourists from different cultural backgrounds. An investigation of the different perceptions of American, French and Chinese travellers towards Vietnam could be particularly valuable with respect to their perceptions of Vietnamese service providers. The current study will examine tourist perceptions of those expectations which were fulfilled based on the service encounters in Vietnam, and those of the Vietnamese hosts as well as the factors that determine these perceptions.

\section{Satisfaction}

According to Pearce and Moscardo (1984), one condition of tourist satisfaction with hosts is the match between tourist and host value orientations. Tourist satisfaction is higher if the value system of the tourist aligns with the value system of the host. Pearce (1991) mentioned that tourist satisfaction is often referred to as the "fit" between expectations and the perceived evaluative outcome of the experience. For instance, the "fit" between tourists and hosts increases when hosts are able to meet tourist expectations. Tourist satisfaction will increase with the degree of fit. Anton (1996) defined customer satisfaction as a state of mind in which the customer's needs, wants and expectations have been met or exceeded throughout the product or service life, resulting in subsequent repurchase and loyalty. Over the past decade, the number of empirical investigations of tourist satisfaction with destinations has increased (Danaher and Arweiler 1996, Qu and Li 1997, Kozak and Rimmington 2000). Some attempts have been made to assess the differences between tourists from different countries visiting the same destination. For example, Sussmann and Rashcovsky (1997) explored the similarities and differences into the vacation travel patterns and attitudes between two groups towards the selected destinations.

In comparing tourist and service providers, Reisinger and Turner (1998) found cultural differences in communication style, expressing feelings, establishing relationships and attitudes between Mandarin tourists and Australian service providers. Although the customer satisfaction literature has been replete with measurements of guest satisfaction with tourism and hospitality services, little work has examined cultural differences. Research into the cross-cultural differences between tourists perceived satisfaction levels with their holiday experiences may contribute to Vietnamese destination manager decision-making with respect to destination positioning and market segmentation strategies. According to Hughes (1991), satisfaction with hosts is the most critical component of the total holiday experience. Tourist satisfaction is unlikely to be achieved unless the tourism industry generally, and front line staff in particular, understand the cultural background of tourists. In the particular case of Vietnam, serving international tourists from different cultural backgrounds may create problems for tourism service providers because of the major cultural differences evident between Western and Asian societies. Vietnam's tourism service providers appear to lack a basic knowledge of the Western and other Asian regions, their people and value orientations. The destination authorities appear to pay limited attention and give minimal recognition to the role of cultural understanding in promoting international tourism. The proposed study will use the direct method of cross-cultural research with surveys completed by tourists. Differences will be identified, where and if these exist, in the perceived satisfaction levels of American, French and Chinese tourists with holiday experiences in Vietnam. A comparative analysis will also be conducted to understand the national similarities and differences between tourists and Vietnamese hosts. To test the various hypotheses, the proposed conceptual model considers the different perceptions and satisfaction 
of international tourists towards Vietnam as a destination generally, and towards Vietnamese service providers in particular. A description of the model is provided with a brief outline of the proposed research method.

\section{A Conceptual Model of Cross-Cultural Holiday Satisfaction}

This paper amalgamates several concepts drawn from the literature and presents them as a conceptual model. This approach aims to enhance our understanding of the influences of holiday satisfaction in a cross-cultural context. The model encompasses concepts drawn from various disciplines including tourism, marketing, psychology and sociology. It is the view of the authors that certain of these approaches have been inadequately acknowledged in the tourism literature, and that no satisfactory explanation has been provided of the relationship with cross-cultural holiday satisfaction. Since holiday satisfaction is a multi-faceted concept, the model gives proper consideration to several independent factors. The variables considered in the model as outlined in Figure 1 are discussed in the following section.

Internal or individual factors are presented as directly determining tourist perceptions and ultimately satisfaction. These factors include different national-cultural indicators such as: (1) the distinct cultural backgrounds of the visitors, (2) the socio-demographic profiles of the visitors (age, sex, occupation) (3) the behavioural and travel characteristics of the visitors (travel mode, travel companion, length of holiday and information search behaviour). The distinct cultural backgrounds of tourists influence perceptions and lead ultimately to differing levels of satisfaction with the holiday experience. The three internal factors noted above contribute to differing tourist perceptions of their hosts. This, in turn affects tourist perceptions of tourism products and services and ultimately perceptions of the overall holiday experience. Different levels of satisfaction arise as a result of various product and service encounters.

External or situational factors are located on the right hand side of the model. These comprise intercultural interactions between the hosts and tourists, and tourist perceptions attached to various destination attributes such as (1) the scope and type of the attributes, (2) the price and quality of available products and services, (3) the personal safety of tourists, and (4) political stability. The following are noted as important factors impacting on tourist perceptions of the holiday experience from a host perspective: cultural values, social interactions with tourists, and tourist perceptions. The achievement of overall holiday satisfaction may be understood in terms of these two interacting components. Satisfaction with hosts is a critical component of the holiday experience and the most prominent determinant of tourist-host interaction is culture. Cultural values determine rules of social interaction and in turn influence tourist perceptions. These perceptions will significantly determine tourist holiday satisfaction or dissatisfaction and will greatly affect post-trip evaluation such as recommendations to others and the prospects of repeat visitation. 
Figure 1: Conceptual Model of Cross-Cultural Holiday Satisfaction

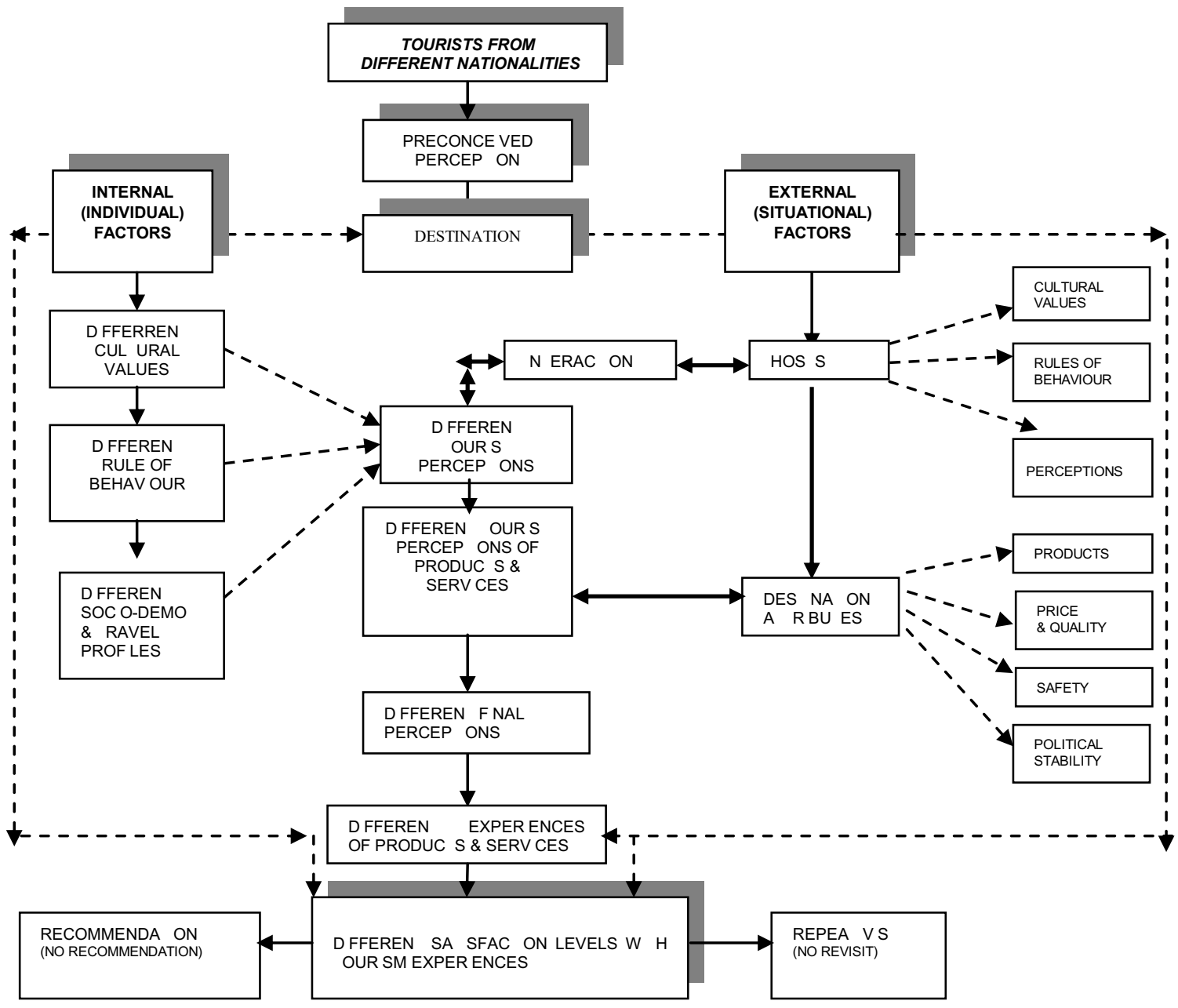

Source: Developed by the Researchers

\section{Research Issues}

The following key research questions provide the chosen line of inquiry into cross-cultural holiday satisfaction based on the subject matter and sequencing proposed in the conceptual model.

- What are the major differences in cultural values and rules of behaviour between American, French and Chinese tourists, and the major differences between the three samples relative to the Vietnamese tourist service providers? Will the tourist cultural values lead to different perceptions and diverse levels of holiday satisfaction?

- How do the differences in cultural values and rules of behaviour of American, French and Chinese tourists impact upon their views and perceptions of Vietnamese products and services in general and the hosts attributes and performances in particular?

- What are the host perspectives of the various tourism products, services and facilities towards their suitability for the three different guest groups?

- What are the key cultural determinants of perception and satisfaction amongst American, French and Chinese tourists? Are there any significant differences between the satisfaction levels exhibited by these tourist groups have when holidaying in Vietnam? 
- Is the prospect of positive word-of-mouth communication and repeat visitation influenced by different attitudes towards perception and satisfaction by Western and Asian tourists? How can the strength and direction of this relationship be identified and measured?

- How might tourism marketers use knowledge of cultural differences between Western and Asian tourists and Vietnamese hosts to develop marketing strategies to develop niche products targeted at each of the three markets with a view to increasing tourist satisfaction and attracting more international tourists to Vietnam?

\section{Methodology and Future Directions}

In terms of future directions, it is expected that testing and refinement of the conceptual model presented in this paper will deliver theory-based outcomes that may be applied to cross-cultural tourism and marketing. Consistent with the objective, the conceptual model will be tested on a sample of international visitors as well as Vietnam based service providers. The proposed sample will be drawn from American, French and Chinese residents visiting Vietnam for leisure purposes. Prospective respondents will be approached randomly in the places of highest visitation. Tourism service providers from a variety of sectors will be surveyed including tour operators and travel agents, and employees within the accommodation, food and beverage and transportation sectors.

Survey questionnaire techniques will be used as the method of collecting data. The survey will attempt to capture the socio-demographics profiles, travel characteristics, cultural values and rules of social behaviour of each population. It will also measure tourist perceptions and satisfaction with Vietnam's holiday attributes in term of tourism products in general, and the hosts' attribute and performances, in particular. A similar instrument will be designed to measure the perceptions of Vietnamese hosts towards tourist satisfaction. The perceptions of hosts concerning cultural differences and levels of satisfaction will then be developed to compare the degree of understanding of these issues amongst tourists and hosts.

A variety of measurement techniques will be used to interpret the data:

- The first part will consist of socio-demographic information gathered from tourists and hosts as well the travel characteristics of the three groups of tourists.

- The second will employ Rokeach's Value Survey (Rokeach, 1973) to compare the values between the American, French, Chinese and Vietnamese cultures.

- The third will utilise Argyle's (1986) instrument to measure the cross-cultural variations governing the rules of relationships.

- The fourth will feature the 10 criteria of service quality developed by Parasuraman et al. (1985, 1988) to measure subject perceptions and satisfaction of the quality of Vietnamese services provided, as well as the inter-perceptions between Vietnamese hosts and international guests.

- The fifth will feature Vietnam's destination attributes (Truong, 2002). It consists of thirty-one attributes and comprises the key variables regarding destination attractiveness, amenities, variety, price, quality of tourism products and services and the safety at the destination.

- The sixth aimed to investigate respondent destination loyalty. Respondents were asked to indicate their intention of repeat visitation to Vietnam and their recommendation of Vietnam to others. 
The quantitative outputs will be analysed using SPSS and will include the following:

- Descriptive statistics will be employed to analyse the socio-demographics of hosts and guests as well as the travel characteristics of the three group of tourists;

- The Mann-Whitney-U test will be applied to compare sample means of the three different groups to test for statistical differences between individual responses; and

- Multivariate techniques will be employed such as cluster analysis, factor analysis and structural equation modelling, e.g. factor analysis will be conducted to establish the dimensions of cultural differences and tourist perceived satisfaction levels of their holiday experiences in Vietnam.

\section{Conclusions}

The aims of the model are both theoretical and practical. The former include identifying the cultural determinants of holiday satisfaction. Practical aims include establishing procedures to help evaluate tourist holiday satisfaction, viewing this as a multi-faceted concept consisting of a number of independent factors. The goal is to understand cultural determinants and the extent to which they influence the degree of tourist holiday satisfaction. It is hoped that the consequences of this influence may be predicted with particular reference to repeat visitation and positive word of mouth communication.

It is anticipated that the model will make a useful contribution to an under-researched aspect of tourism, namely cross-cultural satisfaction between Asian, European and Anglo-Saxon cultures. It should provide researchers with an enhanced understanding of the factors determining tourist satisfaction by undertaking a cross-disciplinary approach to the development and testing of a multivariate conceptual model of cross-national cultural characteristics. The outcomes generated by the testing of this model will have implications for infrastructure planning, product development, facility design, service provision and marketing for inbound holidaymakers not only in Vietnam but also for the tourism sectors internationally.

\section{References}

Anton, J. 1996. Customer Relationship Management: Making Hard Decisions with Soft Number. Prentice-Hall, New Jersey.

Argyle, M. 1978. The Psychology of Interpersonal Behaviour. $3^{\text {rd }}$ ed. USA: Penguin Books.

Argyles, M. 1986. Rules for social relationship in four cultures. Australian Journal of Psychology, 38 (3): 309-318.

Armstrong, R, C. Mok, and F. Go 1997. The Importance of Cross-Cultural Expectations in the Measurement of Service Quality Perceptions in the Hotel industry. International Journal of Hospitality Management, 16 (2): 181-90.

Bennett, P. D. and Kassarjian, H. J. 1972. Consumer Behavior. Englewood Cliffs, New York: Prentice Hall.

Boissevain, J. and Inglott, P. 1979. Tourism in Malta" in De Kadt, E. (Ed), Tourism: Passport to Development, Oxford University Press, Oxford.

Camilleri, C. 1985. La Psychologie Culturelle (Cultural Psychology). Psychologic Francaise 30: 147151.

Catalone R. J.; Di Benedetto C. A.; Halam and Bojanic, D. C. 1989. Multiple Multinational Tourism Positioning using Correspondence Analysis. Journal of Travel Research, 28 (2): 25-32

Cook, M. 1979. Perceiving Others. Methuen, London.

Danaher, P. J. and Arweiler, N. 1996. Customer satisfaction in the tourist industry: A case study of visitors to New Zealand. Journal of Travel Research, Summer: $\quad$ 89-93. 
Ember. C. R. and Ember. M. 1985. Anthropology. 4th ed. New York: Englewood Cliffs. PrenticeHall.

Erez, M and Earley, P. C. 1993. Culture, Self Identity and Work. Oxford University Press, New York.

Gee, C. 1986. Marketing to International Visitors. Unpublished Manuscript. Hawaii: University of Hawaii.

Hall, E.T. 1996. The Hidden Dimension. Garden City, New York, Doubleday and Fawcett Company.

Hall, E.T. 1983. The Dance Of Life: The other Dimensions of Time. New York, Doubleday.

Hall, E.T. 1976. Beyond Culture. New York, Doubleday.

Hargie, O. 1986. A Handbook of Communication Skills. Rutledge, London.

Hofsftede, G. 1980. Culture's Consequences: International Differences, Work-related Values. Beverly Hills, CA, Sage Publications.

Hofstede, G. and Bond, M. H. 1988. The Confucius connection: from cultural roots to economic growth. Organizational Dynamics 16: 5-21.

Hofstede, G. 1991. Cultures and Organisations: Software of the Mind. McGraw-Hill, London.

Hughes, K. 1991. Tourist satisfaction: a guided cultural tour in North Queensland. Australian Psychologist. 26 (3): 166-171.

Huang, J- H., C. T. Huang and S. Wu 1996. National Character and Response to Unsatisfactory Hotel Service. International Journal of Hospitality Management, 15 (3): 229-43.

Ibrahim, H. 1991. Leisure and Society: A Comparative Approach, W. C. Brown, Dubuque, IA.

Kim, Y. Y. and Gudykunst, W. B. 1988. Theories in Intercultural Communication. International and Intercultural Communication Annual 12. Newbury Park, CA: Sage Publications.

Kluckhohn, C. 1944. Mirror For Man. New York: McGraw-Hill.

Kluckhohn 1951. Values and Values Orientations in the Theory of Action, Parsons, T. and Shils, E. A. (Eds) Towards a General Theory of Action, Harvard University Press, Cambridge, Mass, 388-433.

Kroeber. A. and Kluckhohn, C. 1952. Culture: A Critical Review of Concepts and Definitions. Papers of the Peabody Museum of American Archaeology and Ethnology, Harvard University Press 47(1): 223. New York: Random House.

Kluckhohn, C. and Strodbeck, F.L. 1961. Variations in Value Orientation. Harper and Row, New York.

Kozak, M. and Rimmington, M. 2000. Tourist satisfaction with Mallorca, Spain as an off-season holiday destination., Journal of Travel Research 39: 260-269.

Krech, D. and Crutchfield, R. S. (1948) Theory and Problems of Social Psychology. New York: McGraw-Hill.

Leighton, A. H. 1981. Culture and Psychiatry. Journal of Psychiatry 26: 522-529.

Luk, S. T. K; Deleon, C. T; Leong, F. W. and Li, E. L. 1993. Value segmentation of tourists' expectations of service quality. Journal of Travel and Tourism Marketing 2 (4): 23-38.

McCracken, G., (1986), Culture and Consumption: A Theoretical Account of the Structure and Movement of the Cultural Meaning of Consumer Goods. Journal of Consumer Research, 13: 71-84.

Mill, R. C. and Morrison, A. M. 1985. The Tourism System: An Introductory Text. Englewood Cliffs, New Jersey: Prentice Hall.

Millington, K. 2001. Vietnam, country report., EIU Travel and Tourism Analysis 2: 87-97.

Otaki, M; Durrett, M.E; Richards, P; Nyquist, L. and Pennebaker, J. 1986. Maternal and infant behaviour in Japan and America. Journal of Cross-cultural Psychology 17 (3): 251-68.

Parasuraman, A; Zeithaml, V.A. and Berry, L.L. 1985. A conceptual model of service quality and its implications for future research. Journal of Marketing 49: 41-50.

Parasuraman, A; Zeithaml, V.A and Berry, L. L. 1988. SERVQUAL: A multiple-item scale for measuring consumer perceptions of service quality. Journal of Retailing 64: 12-37.

Pearce, P. L. and Moscardo, G. M. 1984. Making sense of tourists' complaints. Tourism Management, 5 (1): 20-23.

Pearce, P. L. 1991. The social and psychological effects of Tourists-Host contact in Bochner, S. (Ed), Cultures in Contact: Studies in Cross-Cultural Interaction, Pergamon Press, Oxford. 
Pizam, A. and Telisman-Kosuta N. 1989. Tourism as a factor of change: results and analysis in Bystrazanowski, J. (Ed), Tourism as a Factor of Change: A Socio-Cultural Study, Vol. 11, European Coordination Centre for Documentation in Social Sciences, Vienna.

Pizam, A. and Sussmann, S., 1995. Does Nationality Affect Tourist Behaviour? Annals of Tourism Research, 22 (4): 901-917.

Pizam, A., Neumann, Y. and Reichel, A. 1996. The effect of nationality on tourist behaviour: Israeli tour-guides perception. Journal of Hospitality and Leisure Marketing, 4 (1): 23-49.

Pizam, A; Pine, R; Mok, C. and Shin, J. Y. 1997. Nationality versus industry cultures: which has greater effect on managerial behaviour? International Journal of Hospitality Management 16 (2): $127-45$.

Pizam, A. 1999. Cross-cultural tourist behaviour, in Pizam, A. and Mansfeld, Y. (Ed), Consumer behavior in Travel and Tourism, Haworth Press, New York.

Porter, R. E. and Samovar, L. A. 1988. Approaching Intercultural Communication, in Samovar, L. A. (Ed), Intercultural Communication: A Reader, Wadsworth, Belmont, California.

$\mathrm{Qu}, \mathrm{H}$; and Li, I. 1997. The characteristics and satisfaction of mainland Chinese visitors to Hong Kong. Journal of Travel Research Spring: 37-41.

Richardson, S; and J. Crompton 1988. Cultural variations in perceptions of vacation attributes. Tourism Management 9 (2): 128-36.

Reisinger, Y. and Turner, L. 1998. Cultural Differences between Mandarin-Speaking tourists and Australian Hosts and their impact on cross-cultural Tourist-Host Interaction, Journal of Business Research 42: 175-187.

Rokeach, M. 1973. The Nature of Human Values. Free Press, New York.

Robertson, T. S. (1970) Consumer Behavior. Glen view. I 11: Scott, Foresman and Company.

Robinson, G. L. N. and Nemetz, L. 1988. Cross-Cultural Understanding. UK: Prentice Hall International.

Samovar, L. A. and Porter, R. E. (1991). Communication between Cultures. Belmont, CA: Wadsworth Publishing Company.

Schiffman, L. G. and Kanuk, L. L. 1987. Consumer Behaviour, Prentice Hall, New Jersey.

Sussmann, S. and Rashcovsky, C. 1997. A cross-cultural analysis of English and French Canadians' vacation travel patterns, International Journal of Hospitality Management 16 (2): 191-208.

Truong, Thuy-Huong (2002), Holiday Satisfaction of Australian Travellers in Vietnam, An Application of the HOLSAT Model", Unpublished Masters Dissertation, RMIT University, Australia.

Usunier, J. C. (2000). Marketing Across Cultures. New York, Financial Times/Prentice Hall

VNAT (Vietnam National Administration for Tourism ) 2003. "Tourist Statistic Visitors", Available from URL www.vietnamtourism.com

Wei, L; Crompton, J. L. and Reid, L. M. 1989. Vacation decisions, activities and satisfactions. Annals of Tourism Research 11: 10-329.

Wei, L., Crompton, J. L. and Reid, L. M. (1989). Cultural Conflicts: Experiences of US Visitors to China. Tourism Management, 10(4): 322-332. 
